\title{
Influence of brassinosteroids on plant cell alternative respiration pathway and antioxidant systems activity under abiotic stress conditions
}

\author{
M. V. Derevyanchuk ${ }^{1}$, O. I. Grabelnyh ${ }^{2}$, R. P. Litvinovskaya ${ }^{3}$, V. K. Voinikov ${ }^{2}$,
}

\author{
A. L. Sauchuk ${ }^{3}$, V. A. Khripach ${ }^{3}$, V.S. Kravets ${ }^{1}$ \\ ${ }^{1}$ Institute of Bioorganic Chemistry and Petrochemistry, NAS of Ukraine \\ 1, Murmanska Str., Kyiv, Ukraine, 02094 \\ ${ }^{2}$ Siberian Institute of Plant Physiology and Biochemistry SB RAS \\ 132, Lermontova Str., Irkutsk, Russian Federation, 664033 \\ ${ }^{3}$ Institute of Bioorganic Chemistry, NAS of Belarus \\ 5, Kuprevicha Str., Minsk, Belarus, 220141 \\ kravets@bpci.kiev.ua
}

\begin{abstract}
Aim. To investigate the brassinosteroids (BRs) influence on the plant alternative respiration pathway and antioxidant systems to regulate the ROS (reactive oxygen species) production under optimal and abiotic stress conditions. Methods. Respiration measurement experiments were done with the polarographic technique. Original methods were used to evaluate the antioxidant systems activity. Results. Treatment with BRs increased the intensity of plant alternative respiration pathway under control and stress conditions. BRs had no effect on alternative respiration of the BR-insensitive bril-6 plants. Brassinosteroids also increased the activity of a range of antioxidant systems under osmotic stress. Conclusions. BRs are involved in the regulation of alternative respiration pathway and antioxidant systems activity in plant cells under optimal and abiotic stress conditions.
\end{abstract}

Keywords: brassinosteroids, alternative oxidase, salt stress, osmotic stress, A. thaliana.

Introduction. Brassinosteroids (BRs) are a novel class of phytohormones implicated as key components of many signal cascades involved in the regulation of cell proliferation and differentiation $[1,2]$, initiations of the adaptive reactions of plant cell metabolism against abiotic [3-5] and biotic [6-8] stresses that often are accompanied by the oxidative stress. Abiotic stresses lead to inhibition of different key systems responsible for the energy and reactive oxygen species (ROS) homeostasis. Particularly, metabolite fluctuations under stress conditions may affect the mETC (mitochondrial electron transport chain) stability by its overloading with electrons that leads to electron leakage. Mitochondria are very sensitive to the redox perturbations caused by the

(C) Institute of Molecular Biology and Genetics, NAS of Ukraine, 2014
ROS production and rapidly respond to environmental factors [9]. The key role in mitochondrial mETC homeostasis is played by alternative oxidase (AOX), which can modulate the level of electrons by oxidizing ubiquinone pool and thus stabilizing the electron flow [10]. AOX activation decreases the ROS level in mitochondria that protects the respiration chain from inhibition and development of oxidative stress [11]. AOX is involved in adaptation to a range of extracellular stresses - macronutrient stress [12], salt [13], drought [14], metals $[15,16]$, pathogens $[17,18]$. It has been shown that roots of the salt-sensitive line of Medicago truncatula plants accumulate 3-fold higher level of hydrogen peroxide comparing to the salt-tolerant cultivar [13]. The $\mathrm{H}_{2} \mathrm{O}_{2}$ level and tolerance to salinity of these cultivars is strictly dependent on the $A O X$ gene expression 
[13]. The transgenic plants overexpressing AOX1a alternative oxidase are characterized with reduced ROS production and better growth $[15,19]$. Despite the intensive experimental work there are a lot of open questions concerning the role of AOX under stress conditions.

In this study we focused on the role of BRs in regulation of the alternative respiration pathway that might constitute an essential part of BR-induced tolerance to abiotic stresses. We have observed that brassinosteroids are involved into the regulation of cyanide-sensitive as well as cyanide-resistant pathways serving for the regulation of ROS formation by mETC and better growth capabilities under stress conditions. Additionally, BRs increased activities of the major antioxidant systems in the plant cell.

Materials and methods. Plant materials and growth conditions. Homozygous stocks of Arabidopsis thaliana Columbia Wild Type (WT) and A. thaliana transgenes were obtained from Nottingham Arabidopsis Stock Centre (NASC, UK): bakl-1 and bril-6 signaling mutants with the «knockout» in components of BR-receptor (BAK1 and BRI1 kinases). In the experiments regarding determination of AOX activity we used leaves of seedlings grown for 18 days on sterile agar plates with $1 / 2$ strenght Moorashige-Skoog (MS) medium supplemented with $1 \%$ of sucrose and hormones or inhibitors. For control conditions no salts were added $(0 \mathrm{mM} \mathrm{NaCl})$. Salt stress conditions were induced with different concentrations of $\mathrm{NaCl}$ in growth medium $(50,75$ and 100 $\mathrm{mM}$ in final concentration). Growth conditions were $22 \pm$ $\pm 2{ }^{\circ} \mathrm{C}$ with a 16 -h photoperiod (photosynthetic photon flux density of $300 \mu \mathrm{mol}$ photons $\mathrm{m}^{-2} \mathrm{~s}^{-1}$ generated with Fluora lamps, «Osram», Germany). For antioxidants analysis the plants were germinated and grown on soil for 21 days. At the $22^{\text {nd }}$ day seedlings were treated with $24-$ epibrassinolide (EBL) solution $\left(10^{-8} \mathrm{M}, 50 \mathrm{ml}\right.$ for every $100 \mathrm{~g}$ of soil with 3-4 plants) and mannitol $(50 \mathrm{ml}$ of $300 \mathrm{mM}$ solution on every $100 \mathrm{~g}$ of soil).

All measurements concerning antioxidants and antioxidant enzymatic systems were made at the $3^{\text {rd }}$ day after stress conditions were initiated.

Chemicals. Brassinazole was obtained from TCI-Europe (Germany), EBL was synthesized in the Laboratory of Steroid Chemistry (Institute of Bioorganic Chemistry, NAS of Belarus), Coomassie blue G250, Nitroblue tetrazolium chloride (NBT) were purchased from «Sig- ma» (USA), other chemicals were obtained from «ALSI» (Ukraine).

Enzyme assay. The samples (500 mg) of A. thaliana leaves were homogenized with a chilled mortar and pestle in $100 \mathrm{mM}$ potassium phosphate buffer $(\mathrm{pH} 7.5)$ containing $0.1 \mathrm{mM}$ EDTA and $1 \%$ of polyvinylpyrrolidone (PVP). The homogenate was centrifuged at $5000 \mathrm{~g}$ for $15 \mathrm{~min}$ at $4{ }^{\circ} \mathrm{C}$ and the supernatant was used for the enzyme activity assays. The total superoxide dismutase (SOD; EC 1.15.1.1) activity was determined by measuring its ability to inhibit the photochemical reduction of nitroblue tetrazolium chloride in Azevedo et al. modification [20]. The catalase (CAT; EC 1.11.1.6) activity was determined according to the technique [21]. The guaiacol peroxidase (GPX; EC 1.11.1.7) activity was determined in terms of formation of tetraguaiacol $(\varepsilon=$ $=26.6 \mathrm{mM}^{-1} \mathrm{~cm}^{-1}$ ) from guaiacol in the reaction mixture containing $1 \mathrm{ml}$ of $5 \mathrm{mM}$ guaiacol, $1 \mathrm{ml}$ of $15 \mathrm{mM} \mathrm{H}_{2} \mathrm{O}_{2}$ and $0.9 \mathrm{ml}$ of potassium phosphate buffer ( $\mathrm{pH} 7.0)$ with $1 \%$ of PVP. The reaction was immediately started by addition of $100 \mu \mathrm{M}$ of enzyme extract and measured spectrophotometrically as the increase of absorption at $470 \mathrm{~nm}$.

Determination of $\mathrm{H}_{2} \mathrm{O}_{2}$ content. Endogenous $\mathrm{H}_{2} \mathrm{O}_{2}$ content was measured by the ferrous ion oxidation xylenol orange (FOX) technique [22] with modifications. Absorbance of colorized complex was read at $560 \mathrm{~nm}$ and $\mathrm{H}_{2} \mathrm{O}_{2}$ content was calculated from a standard curve.

Protein content. Protein concentration was determined according to the method of Bradford with bovine serum albumin as a standard [23].

Determination of proline content. Proline content was determined as described by Bates et al. [24]. The proline concentration was calculated from a standard curve and expressed as $\mu \mathrm{g} / \mathrm{g}$ of fresh weight (FW).

Determination of glutathione content. Glutathione content was determined in the reaction with $5,5^{\prime}$-Dithiobis(2-nitrobenzoic acid) (DTNB) as described by $\mathrm{Yu}$ et al. with modifications [25]. Absorbance was read at $412 \mathrm{~nm}$ and expressed as percents toward control samples.

Investigation of cell respiration activity. The cell respiration activity was measured by monitoring oxygen consumption of the sample $(40 \mathrm{mg})$ in $1 \mathrm{ml}$ of air-saturated buffer (Tris-HCl $5 \mathrm{mM}, \mathrm{pH}$ 6.0) that was thermostated at $25 \pm 0.1^{\circ} \mathrm{C}$. Oxygen concentration was re- 

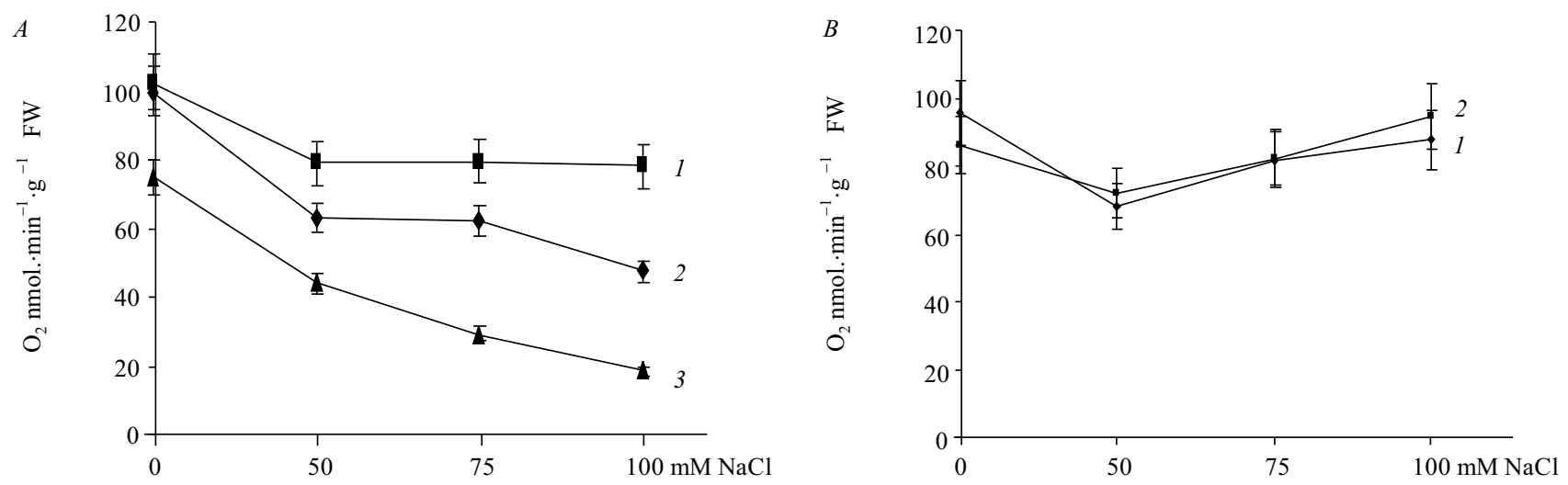

Fig 1. $A$-influence of 24-epibrassinolide (EBL) and brassinazole (BRZ) on alternative oxidase (AOX) respiration rate in wild-type (WT) $A$. thaliana plants under salt stress (1 - WT + EBL; $2-\mathrm{WT} ; 3-\mathrm{WT}+\mathrm{BRZ}) ; B$ - influence of EBL on AOX respiration rate in bri1- 6 A. thaliana plants under salt stress ( 1 - bri 1-6; 2 - bri1-6 + EBL). Seeds were germinated and grown on 1/2 strength MS medium for 18 days prior to analysis. Data are means \pm confidence interval of four replicate boxes

corded with Oxygraph («Hansatech Instruments», United Kingdom) and converted from voltage to oxygen concentration with Oxygraph Plus software («Hansatech Instruments»).

For determination of total respiration rate $\left(\mathrm{V}_{\mathrm{t}}\right)$, cyanide-resistant respiration rate $\left(\mathrm{V}_{\mathrm{KCN}}\right)$ and residual respiration $\left(\mathrm{V}_{\text {res }}\right)$ the inhibitory analysis was used. Potassium cyanide (KCN, $1 \mathrm{mM}$ in final volume) and salicylhydroxamic acid (SHAM, $3 \mathrm{mM}$ in final volume) were used as inhibitors of cytochrome oxidase (CO) and AOX respectively. Maximum activity of alternative respiration $\left(\mathrm{V}_{\text {alt }}\right)$ was measured by adding SHAM in the presence of $\mathrm{KCN}$. The cytochrome oxidase activity $\left(\mathrm{V}_{\text {cyt }}\right)$ was determined after adding of $\mathrm{KCN}$ in the presence of SHAM [26]. The data on figures are presented as $\mathrm{V}_{\text {alt }} /$ $\mathrm{V}_{\mathrm{t}}$ or $\mathrm{V}_{\text {alt }} / \mathrm{V}_{\text {cyt }}$ ratios. The respiration rate is expressed as nmol $\mathrm{O}_{2} \cdot \mathrm{min}^{-1} \cdot \mathrm{g}^{-1} \mathrm{FW}$.

Statistical analysis. Each experiment was repeated at least three times, each with three technical replicates. The values on figures represent means of 3-4 biological replicates ( $n=15$ seedlings) with the confidence intervals at 0.05 level of significance.

Results and discussion. EBL activates alternative respiration pathway under abiotic stress conditions. We analyzed a role of BRs in plant respiration and its connection with the ROS homeostasis and antioxidant systems activity under salt stress. We have observed that EBL impairs alternative respiration pathway under control and salinity conditions in $A$. thaliana. AOX respiration was significantly increased by BRs under stress conditions by $60 \%$ while brassinazole, inhibitor of
BRs biosynthesis, suppressed alternative respiration by $50 \%$ (Fig. 1, A). Thus the rate of alternative respiration to total respiration has been elevated from 0.4 to 0.6 in WT plants treated with EBL; the same was for the ratio of AOX pathway/CO respiration (from 0.9 to 1.6) (Fig. 2, $A, B$ ).

The $\mathrm{AOX} / \mathrm{CO}$ and $\mathrm{AOX} /$ total respiration ratios were stimulated by EBL while brassinazole treatment strongly decreased these proportions (Fig. 2, $A, B$ ). High ratio of alternative respiration to main respiration pathway provides a reliable mechanism for regulation of the ROS production by mETC. In contrast to col1 plants, bri1-6 maintained high level of alternative respiration in control conditions and under salt stress (Fig. 1, $B$ ). The AOX/ total respiration and $\mathrm{AOX} / \mathrm{CO}$ ratios in bril-6 have been almost unaffected neither by EBL treatment nor by salt stress conditions (Fig. 3, $A, B$ ) and strongly reduced in comparison to coll plants. Moreover, both bril-6 plants and WT plants treated with brassinazole are characterized with strongly reduced growth (Fig. 4). Thus, high rate of main respiration pathway with high AOX activity of bri1-6 plants produces almost the same growth phenotype as the low-intensity main respiration of WT plants with low BRs content. It may point at inefficient regulation of the mETC activity and energy substrates consumption in the absence of BRs signaling and evident role of BRs in the regulation of energy homeostasis under stress.

Influence of EBL on antioxidants balance and antioxidant enzymes activity under abiotic stress. Stress conditions and EBL had a significant impact on antioxi- 

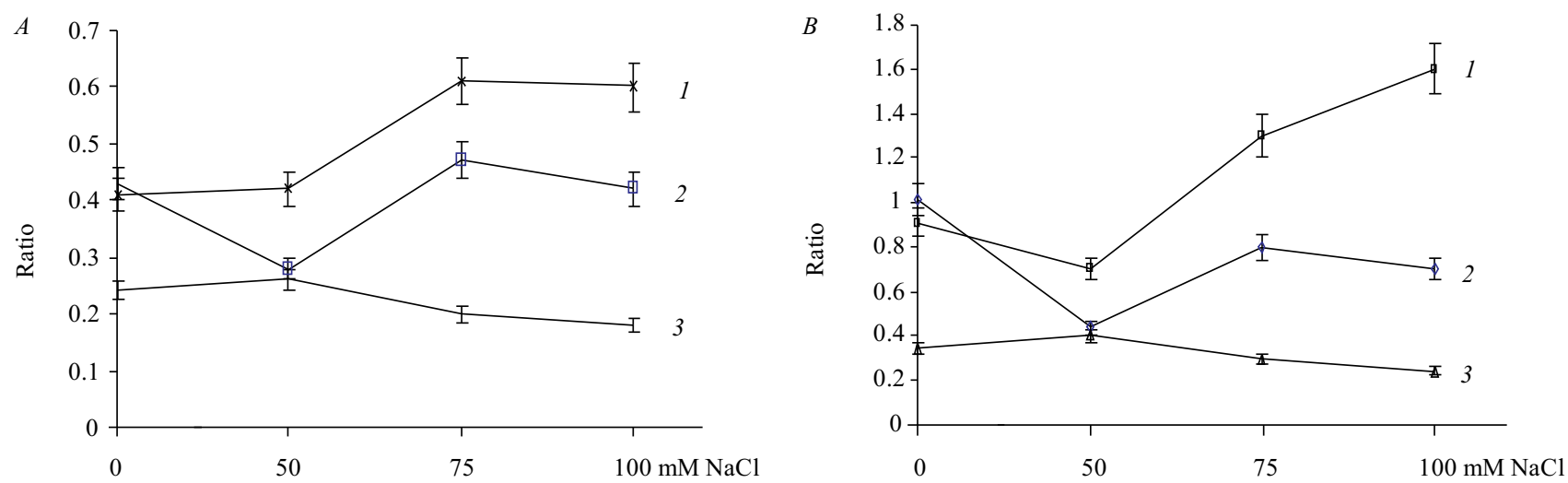

Fig. 2. $A$-influence of 24-epibrassinolide (EBL) and brassinazole (BRZ) on alternative oxidase (AOX) respiration/total respiration ratio in wildtype (WT) $A$. thaliana plants under salt stress ( $1-\mathrm{WT}+\mathrm{EBL} ; 2-\mathrm{WT} ; 3-\mathrm{WT}+\mathrm{BRZ}$ ); $B$ - influence of EBL on AOX respiration/CO respiration ratio in WT A. thaliana plants under salt stress ( 1 - WT + EBL; 2 - WT; $3-\mathrm{WT}+\mathrm{BRZ}$ ). Seeds were germinated and grown on 1/2 strength MS medium for 18 days prior to analysis. Data are means \pm confidence interval of four replicate boxes
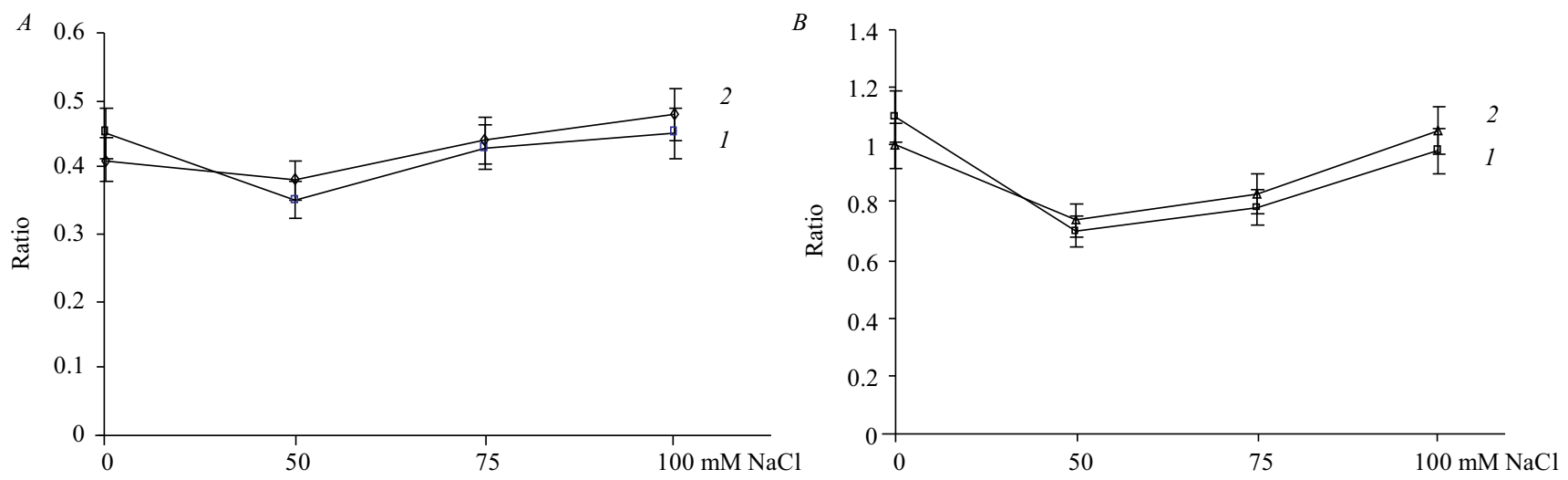

Fig. 3. $A$-influence of 24-epibrassinolide (EBL) on alternative oxidase (AOX) respiration/total respiration ratio in bri1-6 A. thaliana plants under salt stress (1 - bri1-6; 2 - bri1-6 + EBL); B - influence of EBL on AOX respiration/CO respiration ratio in bri1-6 A. thaliana plants under salt stress ( 1 - bril-6;2-bri1-6+EBL). Seeds were germinated and grown on 1/2 strength MS medium for 18 days prior to analysis. Data are means \pm confidence interval of four replicate boxes

dant systems (Table). We have found that under control conditions EBL induces glutathione accumulation that is the major antioxidant in mitochondria. We also observed that proline level was significantly elevated by the hormone under osmotic stress which can serve not only as important osmoprotector but also as ROS scavenger [27]. Analysis of the hydrogen peroxide level showed a decrease in hydrogen peroxide content in bakl-1 plants compared to the WT plants. It is known that a slightly increased $\mathrm{H}_{2} \mathrm{O}_{2}$ level stimulates the accumulation of different antioxidants including glutathione [28]. The activity of catalase was strongly promoted by the hormone under osmotic stress. Superoxide dismutase was activated by EBL in control conditions but inhibited under stress. The guaiacol peroxidase activity was strongly suppressed by EBL (Table) that might be a result of a possible production of hydroxyl radicals. It is already known that BRs differently regulate the activity of enzymatic antioxidants under specific stress conditions. The valuable information may be obtained from these measurements in association with the AOX activity. The activation of catalase by EBL is an important parameter in terms of particular localization of catalases in peroxisomes and mitochondria of the plant cell [29]. Thus it may be an evidence of importance of the BRs signaling pathway in mediating the ROS accumulation and ROS cascades in the adaptation response.

It was observed that EBL activates the AOX activity (Fig. 1) that might be a part of the mechanism of BR-induced cell tolerance to salt stress. mETC might determine the cell metabolism adaptation strategy to stress action [30] and we suggest that BRs may modify this 

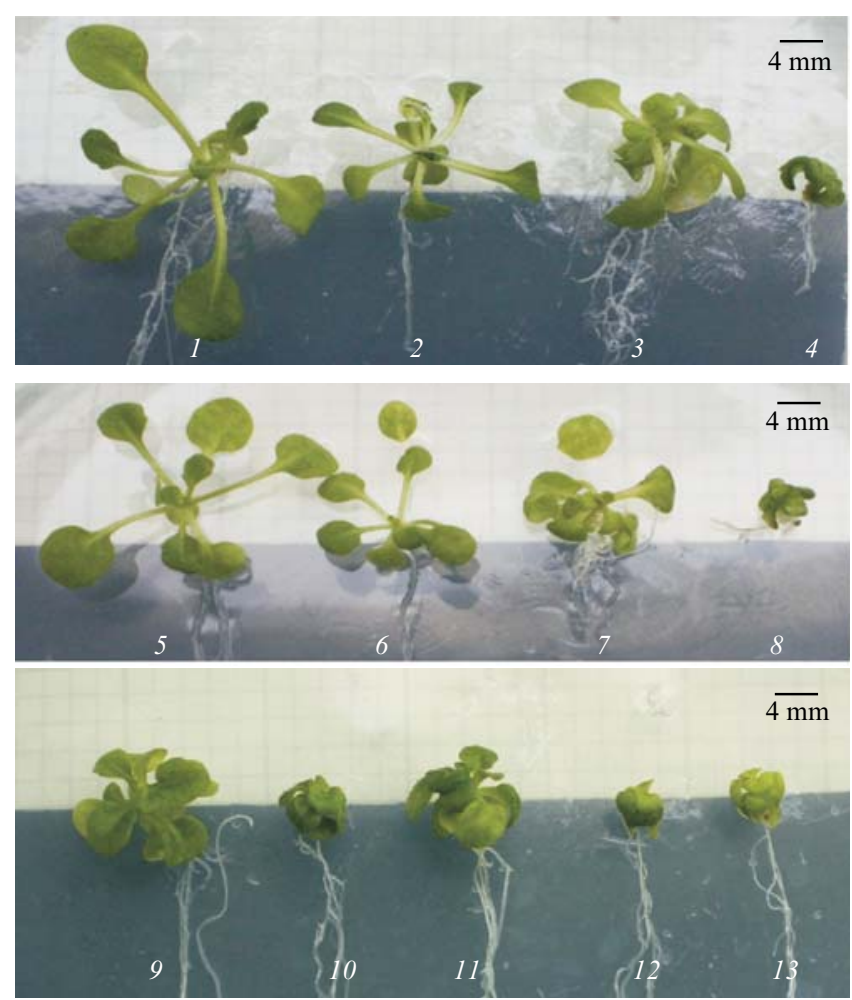

Fig. 4. Phenotype of wild-type (WT) and bril-6 plants treated with $10^{-8} \mathrm{M}$ 24-epibrassinolide (EBL) and $10^{-6} \mathrm{M}$ brassinazole (BZR) under salt stress (plants were germinated and grown for 18 days in the presence of hormone or inhibitor under salt stress conditions): 1,5-WT; $2-\mathrm{WT}+$ $\mathrm{NaCl}, 75 \mathrm{mM} ; 3-\mathrm{WT}+\mathrm{NaCl}, 75 \mathrm{mM}+\mathrm{EBL} ; 4-\mathrm{WT}+\mathrm{NaCl}, 75 \mathrm{mM}+$ $\mathrm{BZR} ; 6-\mathrm{WT}+\mathrm{NaCl}, 100 \mathrm{mM} ; 7-\mathrm{WT}+\mathrm{NaCl}, 100 \mathrm{mM}+\mathrm{EBL} ; 8-$ $\mathrm{WT}+\mathrm{NaCl}, 100 \mathrm{mM}+\mathrm{BZR}$; - bril-6; 10- bri1-6 + NaCl, $75 \mathrm{mM} ; 11-$ bri1-6; 12 - bri1-6+ NaCl, $100 \mathrm{mM} ; 13-$ bri1-6+ NaCl, $100 \mathrm{mM}+\mathrm{EBL}$

program. Under salt stress conditions the BR-insensitive plants slightly changed their total respiration rate (data not shown). This points at BRs involvement in the regulation of plant total respiration. A low respiration rate facilitates the energy substrates preservation which in stress conditions may assure an adequate ATP reserve. The strategy with high-intensive respiration is highly effective under the short-term stresses whereas the reduction of respiration rate is more efficient under the long-term stress conditions. Under long-term stress this was accompanied by improved growth under the stress conditions (Fig. 4, $B$ ). The elevated AOX/CO ratio improves a cell capacity of oxygen consumption by alternative oxidase preventing possible mETC overloading, ROS production and ROS-induced self-inhibition.

BRs not only influence the alternative respiration activity under abiotic stress but play a role in the development of a systemic response involving different antioxidants. We have found that BRs influenced the glu- tathione level under the control conditions and proline content under the stress conditions (Table). Proline may greatly contribute to the energy homeostasis during the salt stress providing electrons to $\mathrm{mETC}[31]$ and stabilizing Complex II of mETC [32]. Glutathione level positively correlates with the plant resistance to oxidative stress [33].

BRs are essential for ROS signaling in induction of cell tolerance to the abiotic stress [34]. We have found that the BR-signaling mutant bakl-1 possesses a lower level of hydrogen peroxide (Table). The possible explanation is that a strong long-term BRs deficiency may generate the stress conditions by itself and promote the antioxidants activity as a part of non-specific response. More importantly the BR-deficient det2 mutants also accumulate less hydrogen peroxide and demonstrate induced tolerance to the oxidative stress [35]. However, det 2 is characterized with a high sensitivity to the salt stress likely because of disordered ROS-signaling [36].

In plants, $\mathrm{H}_{2} \mathrm{O}_{2}$ significantly increases the gene expression of antioxidant enzymes and enzymes of the alternative respiration pathway such as ALTERNATIVE NADH-DEHYDROGENASES and ALTERNATIVE OXIDASES [37]. mETC-derived ROS might also contribute to the cell signaling during adaptation to the biotic stress [38]. Thus, modulation of the hydrogen peroxide level inside a cell may determine necessary crosstalk between ROS signaling and other signaling cascades in maintaining metabolism reorganization in response to the stress.

Conclusions. BRs contributed to the activation of an alternative respiration pathway of mitochondria and the rate of growth under salt stress. The reduction of endogenous BRs level with inhibitor brassinazole decreased the alternative respiration in $A$. thaliana plants and increased the sensitivity of plants to saline environments.

The treatment with exogenous BRs showed no influence on the intensity of alternative respiration pathway in the transgenic BR-signaling line bril-6 under control and stress conditions

The antioxidant enzymatic activity and level of proline greatly increased under the BRs treatment at osmotic conditions.

Funding. This work was supported by the State Fund for Fundamental Researches of Ukraine (grant N $\Phi 54.4 /$ 
Activity of enzymatic antioxidant systems in A. thaliana - GPX $\left(\mathrm{mM} \mathrm{H}_{2} \mathrm{O}_{2} \cdot \mathrm{min}^{-1} \cdot \mathrm{mg}^{-1} \cdot\right.$ protein $), \mathrm{CAT}\left(\mu \mathrm{M} \mathrm{H} \mathrm{H}_{2} \cdot \mathrm{min}^{-1} \cdot \mathrm{mg}^{-1} \cdot \mathrm{protein}\right), \mathrm{SOD}$ (Units $\cdot \mathrm{mg}^{-1} \cdot$ protein) and content of $\mathrm{H}_{2} \mathrm{O}_{2}\left(\mu \mathrm{M} \cdot \mathrm{g}^{-1} \mathrm{FW}\right), \mathrm{MDA}\left(\mathrm{nM} \cdot \mathrm{g}^{-1} \mathrm{FW}\right)$, proline $\left(\mu \mathrm{g} \cdot \mathrm{g}^{-1} \mathrm{FW}\right)$, glutathione (\% of control) after 2 days of osmotic stress action (300 $\mathrm{mM}$ mannitol)

\begin{tabular}{|c|c|c|c|c|}
\hline Variant & Control & $\mathrm{EBL}, 10^{-7} \mathrm{M}$ & Mannitol & Mannitol + EBL \\
\hline \multicolumn{5}{|l|}{$\mathrm{H}_{2} \mathrm{O}_{2}$} \\
\hline WT & $432.17 \pm 17.77$ & $406.53 \pm 16.98$ & $387.31 \pm 16.38$ & $419.35 \pm 17.38$ \\
\hline bakl & $278.37 \pm 13.01$ & $380.90 \pm 16.18$ & $368.08 \pm 15.79$ & $387.26 \pm 16.38$ \\
\hline \multicolumn{5}{|l|}{ GPX } \\
\hline WT & $12.05 \pm 0.42$ & $8.05 \pm 0.58$ & $13.43 \pm 1.99$ & $7.99 \pm 1.52$ \\
\hline \multicolumn{5}{|l|}{ CAT } \\
\hline WT & $17.53 \pm 0.99$ & $16.88 \pm 0.95$ & $23.57 \pm 1.33$ & $39.28 \pm 2.22$ \\
\hline \multicolumn{5}{|l|}{ SOD } \\
\hline WT & $15.01 \pm 0.75$ & $21.86 \pm 1.09$ & $32.43 \pm 1.62$ & $23.08 \pm 1.15$ \\
\hline \multicolumn{5}{|l|}{ Proline } \\
\hline WT & $15.75 \pm 0.79$ & $14.70 \pm 0.73$ & $51.19 \pm 2.56$ & $108.94 \pm 5.45$ \\
\hline \multicolumn{5}{|l|}{ Glutathione } \\
\hline WT & $100.0 \pm 2,8$ & $119.4 \pm 3,1$ & $116.7 \pm 4,7$ & $120.8 \pm 5,8$ \\
\hline
\end{tabular}

N o t e. bakl for GPX, CAT and SOD not determined.

026-2013), NAS of Ukraine (N 2.1.10.32-10) and Belarusian Republican Foundation for Fundamental Research (N X13K-094).

Вплив брасиностероїдів на альтернативний шлях дихання клітин рослин та активність антиоксидантних систем за умов абіотичних стресів

М. В. Дерев'янчук, О. І. Грабельних, Р. П. Литвіновськая, В. К. Войніков, А. Л. Савчук, В. О. Хрипач, В. С. Кравець

Резюме

Мета. Дослідити вплив брасиностероїдів (БС) на альтернативний шилях дихання рослин та антиоксидантні системи для регуляиії прочесів утворення активних форм кисню (АФК) за оптимальних і стресових умов. Методи. Інтенсивність дихання вимірюва ли методом полярографії. Активність антиоксидантних систем визначали оригінальними методами. Результати. Обробка БС підвищувала інтенсивність альтернативного шляху дихання рослин за оптимальних і стресових умов. БС не впливали на альтернативний шлях рослин bri1-6, нечутливих до дї БС. Брасиностероїди підвищували також активність низки антиоксидантних систем за умов осмотичного стресу. Висновки. БС залучені до регуляиії альтернативного шляху дихання та активності антиоксидантних систем у клітинах рослин за контрольних умов та умов абіотичних стресів.

Ключові слова: брасиностероїди, альтернативна оксидаза, сольовий стрес, осмотичний стрес, A. thaliana.
Влияние брассиностероидов на альтернативный путь дыхания клеток растений и активность антиоксидантных систем в условиях абиотических стрессов

М. В. Деревянчук, О. И. Грабельных, Р. П. Литвиновская, В. К. Войников, А. Л. Савчук, В. А. Хрипач, В. С. Кравец Резюме

Цель. Исследовать влияние брассиностеродиов (БС) на альтернативный путь дыхания растений и антиоксидантные системы для регуляиии прочессов образования активных форм кислорода (АФК) в оптимальных и стрессовых условиях. Методы. Интенсивность дыхания измеряли методом полярографии. Активность антиоксидантных систем определяли оригинальными методами. Результаты. Обработка БС повымала интенсивность альтернативного пути дыхания растений в контрольных и стрессовых условиях. БС не влияли на альтернативный путь дыхания растений bri1-6, нечувствительных к действию БС. Брассиностероиды также повышали активность ряда антиоксидантных систем в условиях осмотического стресса. Выводы. БС вовлечены в регуляиию альтернативного пути дыхания и активности антиоксидантных систем клеток растений в контрольных условиях и в условиях абиотичесских стрессов.

Ключевые слова: брассиностероиды, альтернативная оксидаза, солевой стресс, осмотический стресс, A. thaliana.

\section{REFERENCES}

1. Khripach V, Zhabinskii V, De Groot A. Twenty years of brassinosteroids: steroidal plant hormones warrant better crops for the XXI century. Ann Bot. 2000; 86(3): 441-7. 
2. Goda H, Sawa S, Asami T, Fujioka S, Shimada Y, Yoshida S. Comprehensive comparison of auxin-regulated and brassinosteroid-regulated genes in Arabidopsis. Plant Physiol. 2004; 134(4):1555-73.

3. Kagale S, Divi UK, Krochko JE, Keller WA, Krishna P. Brassinosteroid confers tolerance in Arabidopsis thaliana and Brassica napus to a range of abiotic stresses. Planta. 2007;225(2):353-64.

4. Ahammed GJ, Choudhary SP, Chen S, et al. Role of brassinosteroids in alleviation of phenanthrene-cadmium co-contamination-induced photosynthetic inhibition and oxidative stress in tomato. J Exp Bot. 2013;64(1):199-213.

5. Dhaubhadel S, Browning KS, Gallie DR, Krishna P. Brassinosteroid functions to protect the translational machinery and heatshock protein synthesis following thermal stress. Plant J. 2002; 29(6):681-91.

6. Wang $Z Y$. Brassinosteroids modulate plant immunity at multiple levels. Proc Natl Acad Sci US A. 2012;109(1):7-8.

7. Kaur R, Ohri P, Bhardwaj R. Effect of 28-homobrassinolide on susceptible and resistant cultivars of tomato after nematode inoculation. Plant Growth Regul. 2013; 71(3): 199-205.

8. Ali SS, Kumar GB, Khan M, Doohan FM. Brassinosteroid enhances resistance to fusarium diseases of barley. Phytopathology. 2013;103(12):1260-7.

9. Searle SY, Thomas S, Griffin KL, et al. Leaf respiration and alternative oxidase in field-grown alpine grasses respond to natural changes in temperature and light. New Phytol. 2011;189(4): 1027-39.

10. Van Aken O, Giraud E, Clifton R, Whelan J. Alternative oxidase: a target and regulator of stress responses. Physiol Plant. 2009; 137(4):354-61.

11. Cvetkovska M, Vanlerberghe GC. Alternative oxidase modulates leaf mitochondrial concentrations of superoxide and nitric oxide. New Phytol. 2012;195(1):32-9.

12. Sieger SM, Kristensen BK, Robson CA, et al. The role of alternative oxidase in modulating carbon use efficiency and growth during macronutrient stress in tobacco cells. J Exp Bot. 2005; 56 (416):1499-515.

13. Mhadhbi H, Fotopoulos V, Mylona PV, Jebara M, Aouani ME, Polidoros $A N$. Alternative oxidase 1 (Aox1) gene expression in roots of Medicago truncatula is a genotype-specific component of salt stress tolerance. J Plant Physiol. 2013;170(1):111-4.

14. Wang J, Vanlerberghe GC. A lack of mitochondrial alternative oxidase compromises capacity to recover from severe drought stress. Physiol Plant. 2013; 149(4): 461-73

15. Panda SK, Sahoo L, Katsuhara M, Matsumoto H. Overexpression of alternative oxidase gene confers aluminum tolerance by altering the respiratory capacity and the response to oxidative stress in tobacco cells. Mol Biotechnol. 2013;54(2):551-63.

16. Liu J, Li Z, Wang Y, Xing D. Overexpression of ALTERNATIVE OXIDASE1a alleviates mitochondria-dependent programmed cell death induced by aluminium phytotoxicity in Arabidopsis. J Exp Bot. 2014;65(15):4465-78.

17. Cvetkovska $M$, Vanlerberghe $G C$. Coordination of a mitochondrial superoxide burst during the hypersensitive response to bacterial pathogen in Nicotiana tabacum. Plant Cell Environ. 2012; 35(6):1121-36.

18. Cvetkovska $M$, Vanlerberghe GC. Alternative oxidase impacts the plant response to biotic stress by influencing the mitochondrial generation of reactive oxygen species. Plant Cell Environ. 2013;36(3):721-32.

19. Smith CA, Melino VJ, Sweetman C, Soole KL. Manipulation of alternative oxidase can influence salt tolerance in Arabidopsis thaliana. Physiol Plant. 2009;137(4):459-72.
20. de Azevedo Neto AD, Prisco JT, Eneas-Filho J, de Abreu CEB, Gomes-Filho E. Effect of salt stress on antioxidative enzymes and lipid peroxidation in leaves and roots of salt-tolerant and saltsensitive maize genotypes. Environ Exp Bot. 2006; 56(1):87-94.

21. Monnet F, Bordas F, Deluchat V, Baudu M. Toxicity of copper excess on the lichen Dermatocarpon luridum: antioxidant enzyme activities. Chemosphere. 2006;65(10):1806-13.

22. Pinto Mdel C, Tejeda A, Duque AL, Macias P. Determination of lipoxygenase activity in plant extracts using a modified ferrous oxidation-xylenol orange assay. J Agric Food Chem. 2007;55 (15): 5956-9.

23. Bradford $M M$. A rapid and sensitive method for the quantitation of microgram quantities of protein utilizing the principle of protein-dye binding. Anal Biochem. 1976;72:248-54.

24. Bates LS, Waldren RP, Teare ID. Rapid determination of free proline for water-stress studies. Plant Soil. 1973; 39(1):205-7.

25. Yu C-W, Murphy TM, Sung $W-W$, Lin $C-H . \mathrm{H}_{2} \mathrm{O}_{2}$ treatment induces glutathione accumulation and chilling tolerance in mung bean. Funct Plant Biol. 2002; 29(9):1081-7.

26. Moller IM, Berczi A, van der Plas LHW, Lambers H. Measurement of the activity and capacity of the alternative pathway in intact plant tissues: Identification of problems and possible solutions. Physiol Plant. 1988; 72(3): 642-9.

27. Smirnoff $N$, Cumbes $Q J$. Hydroxyl radical scavenging activity of compatible solutes. Phytochemistry 1989; 28(4):1057-60.

28. Queval G, Jaillard D, Zechmann B, Noctor G. Increased intracellular $\mathrm{H}_{2} \mathrm{O}_{2}$ availability preferentially drives glutathione accumulation in vacuoles and chloroplasts. Plant Cell Environ. 2011;34 (1):21-32.

29. Zamocky M, Furtmuller PG, Obinger C. Evolution of catalases from bacteria to humans. Antioxid Redox Signal. 2008;10(9): $1527-48$.

30. Jacoby RP, Taylor NL, Millar AH. The role of mitochondrial respiration in salinity tolerance. Trends Plant Sci. 2011;16(11):614-23.

31. Hare PD, Cress $W A$. Metabolic implications of stress-induced proline accumulation in plants. Plant Growth Regul. 1997;21 (2):79-102.

32. Hamilton EW 3rd, Heckathorn SA. Mitochondrial adaptations to $\mathrm{NaCl}$. Complex I is protected by anti-oxidants and small heat shock proteins, whereas complex II is protected by proline and betaine. Plant Physiol. 2001;126(3):1266-74.

33. Dubreuil-Maurizi C, VitecekJ, Marty L, et al. Glutathione deficiency of the Arabidopsis mutant pad2-1 affects oxidative stressrelated events, defense gene expression, and the hypersensitive response. Plant Physiol. 2011;157(4):2000-12.

34. Cui JX, Zhou YH, Ding JG, et al. Role of nitric oxide in hydrogen peroxide-dependent induction of abiotic stress tolerance by brassinosteroids in cucumber. Plant Cell Environ. 2011;34(2): 347-58.

35. Cao $S, X u Q$, Cao $Y$, et al. Loss-of-function mutations in DET2 gene lead to an enhanced resistance to oxidative stress in Arabidopsis. Physiol Plant. 2005; 123(1): 57-66.

36. Zeng H, Tang Q, Hua X. Arabidopsis brassinosteroid mutants det2-1 and bin2-1 display altered salt tolerance. J Plant Growth Regul. 2010; 29(1): 44-52.

37. Vergara $R$, Parada F, Rubio $S$, Perez FJ. Hypoxia induces $\mathrm{H}_{2} \mathrm{O}_{2}$ production and activates antioxidant defence system in grapevine buds through mediation of $\mathrm{H}_{2} \mathrm{O}_{2}$ and ethylene. $J$ Exp Bot. 2012;63(11):4123-31.

38. Cvetkovska $M$, Alber NA, Vanlerberghe GC. The signaling role of a mitochondrial superoxide burst during stress. Plant Signal Behav. 2013;8(1):e22749.

Received 27.06.14 